\title{
GAY RIGHTS IN THE EU: A LONG WAY FORWARD FOR THE UNION OF 27
}

\author{
Dimitry Kochenov*
}

Some Member States hide behind the principle of subsidiarity in order to legitimise discrimination.

Sophia in 't Veld MEP'

Summary: This article provides a summary of the evolution of gay rights in the European Union. It highlights some legal lacunae in the protection of these rights which should be dealt with, and provides a sketch of the necessary developments in the near future. It identifies the main lines of gay rights development in the context of European integration, and views it from the larger perspective of other jurisdictions. Attention is given to Directive 2000/78/EC and the general context of transformation and enlargement, in which the Union has added a number of Member States that can be characterised as more homophobic than not. The article provides several illustrations of negative developments in gay rights in Eastern Europe, particularly in the new Member States of Latvia and Poland. In addition to the challenge of enlargement, it argues, Directive 2000/78/EC itself is far from an ideal instrument for assisting European gays. Rather, it only marks the first step forward, with many challenges lying ahead.

\section{Introduction: Three Disturbing Lines of Development}

With the entry into force of Directive $2000 / 78 / \mathrm{EC},{ }^{2}$ a false impression might be gained that gay rights enjoy adequate protection in Europe,

\footnotetext{
* Dimitry Kochenov, PhD (Groningen), LLM (CEU, Budapest), Universitair Docent, University of Groningen. Parts of this article develop the analysis contained in D Kochenov, 'Democracy and Human Rights - Not for Gay People? EU Eastern Enlargement and Its Impact on the Protection of the Rights of Sexual Minorities' (2007) 13 Texas Wesleyan LR (forthcoming). The author is grateful to Professor Fiona Beveridge for her comments and her kind invitation to present the initial draft of this work at an equality law workshop in Zagreb in autumn 2006; to Professor Siniša Rodin; and also to Professor Mari Nagata, whose kindness and hospitality made it possible to finish this article during a guest lectureship at the Osaka Graduate School of Law in the early summer of 2007.

1 Remarks during the debate on the Resolution on homophobia in Europe, 16 January 2006, PV 16/01/2006-14.

2 Council Directive 2000/78/EC of 27 November 2000 establishing a general framework for equal treatment in employment and occupation [2000] OJ L303/16. On this directive, see D Schiek, 'A New Framework on Equal Treatment of Persons in EC Law?' (2002) 8 Eur LJ 290; B Koopman, 'De bijzondere inkadering van de Algemene Kaderrichtlijn' (2001) 5 Nederlands tijdschrift voor Europees recht 126. In the context of other equality instruments, see L Waddington and M Bell, 'More Equal than Others: Distinguishing European Union Equality Directives' (2001) 38 CML Rev 587.
} 
and that the law of the Community and its Member States is sufficiently well-developed to effectively protect the dignity of the gay, lesbian and bisexual population of the European Union $(\mathrm{EU})^{3}$ and ensure equal treatment. Unfortunately, the EU still has a long way to go towards gay rights protection. The Directive should thus be viewed as a first step in the right direction, rather than the final goal.

This article provides a summary of the development of gay rights in the European Union, and highlights some legal lacunae in the protection of these rights that should be dealt with. It covers the ECJ's disappointing Grant case law on non-discrimination based on sexual orientation, ${ }^{4}$ contrasting it with calls by the European Parliament ${ }^{5}$ to move forward beyond the Court's archaic and illogical stance ${ }^{6}$ and broaden the current approach to non-discrimination based on sexual orientation in the EU. ${ }^{7}$ Identifying the main lines of gay rights development in the context of European integration, the evolution of gay rights in the EU is viewed from the larger perspective of other jurisdictions. Nor is the context of transformation, in which such recent innovations as Directive 2000/78/ EC emerged, neglected here. The Union has changed forever following the two recent rounds of enlargement, ${ }^{8}$ incorporating 12 new Member States. ${ }^{9}$ Having reshuffled all the important balance points in European institutions $^{10}$ and added a number of Member States which can be characterised as more homophobic than not, enlargement represents an important

\footnotetext{
3 The term 'gay' is used hereinafter in reference to lesbian women, homosexual men and bisexuals.

4 Case C-249/96 Lisa Jacqueline Grant $v$ South-West Trains Ltd [1998] ECR I-621; Cases C-122/99P \& C-125/99P D \& Sweden v Council [2001] ECR I-4319.

5 European Parliament, 'Resolution on equal rights for homosexuals and lesbians in the EC' [1994] OJ C61/40; European Parliament, 'Resolution on equal rights for gays and lesbians in the EC' [1998] OJ C313/186. See also several relevant later resolutions: European Parliament, 'Resolution on homophobia in Europe' (2006) Texts Adopted P6_TA(2006)0018; European Parliament, 'Resolution on the increase in racist and homophobic violence in Europe' (2006) Texts Adopted P6_TA(2006)0273; European Parliament, 'Resolution on homophobia in Europe' (2007) Texts Adopted P6_TA-PROV(2007)0167.

6 See Section I below.

7 See especially European Parliament, 'Recommendation on the future of the area of freedom, security and justice' [2005] OJ C166/58.

8 On the legal regulation of enlargements, see A Ott and K Inglis (eds), Handbook on European Enlargement (TMC Asser Press, The Hague 2002). See also D Kochenov, 'EU Enlargement Law: History and Recent Developments: Treaty-Custom Concubinage?' (2005) 9(6) EIoP 1 (with an exhaustive list of books on this issue in $\mathrm{fn} 2$ ) <http://eiop.or.at/eiop/ texte/2005-006.htm> accessed 31 July 2007.

9 See the 2003 Treaty of Accession [2003] OJ L236 and the 2005 Treaty of Accession [2005] OJ L157.

10 L Friis, “"The End of the Beginning” of Eastern Enlargement - Luxembourg Summit and Agenda Setting' (1998) 7(2) EIoP 1, 3 <http://eiop.or.at/eiop/texte/1998-007.htm> accessed 31 July 2007.
} 
dividing line for gay rights protection in Europe. ${ }^{11}$ This paper provides several illustrations of negative developments in gay rights in Eastern Europe, particularly in the new Member States of Latvia and Poland. Such developments include Equality Parade prohibitions, repressive policies vis-à-vis openly gay staff in schools, homophobic hate speech by senior officials, and the failure of some Member States to implement the Directive properly. ${ }^{12}$ Moreover, the article argues that the Directive itself is far from being an ideal instrument to help European gays. Likewise, other EC legislation, such as Directive 2004/38/EC on the free movement of citizens, ${ }^{13}$ Directive 2003/109/EC on the free movement of third-country nationals who are long-term residents, ${ }^{14}$ and Directive 2003/86/EC on family reunification ${ }^{15}$ all fall short of ensuring full protection for gay rights, if they even pay due attention to this issue at all.

It thus emerges that progress in the area of gay rights in the EU is negatively affected by developments of three different kinds. The first of these may be viewed as belonging to EU legal history, or even the absence of modern ECJ case law on the subject. The Court's pre-Directive 2000/78/EC case law can only be compared to the US Supreme Court's miscegenation case law in the $19^{\text {th }}$ century. ${ }^{16}$ Instead of interpreting the sex-based discrimination prohibited by Community law as covering discrimination based on sexual orientation, as other international courts have done, ${ }^{17}$ the ECJ has preferred to make gays' lives difficult by draft-

11 On gay rights in relation to EU enlargement, see D Kochenov, 'Democracy and Human Rights - Not for Gay People? EU Eastern Enlargement and Its Impact on the Protection of the Rights of Sexual Minorities' (2007) 13 Texas Wesleyan LR (forthcoming); TJ Langekamp, 'Finding Fundamental Fairness: Protecting the Rights of Homosexuals under European Union Accession Law' (2003) 4 San Diego Intl LJ 437.

12 See Section II below.

13 Directive 2004/38/EC of the European Parliament and of the Council of 29 April 2004 on the right of citizens of the Union and their family members to move and reside freely within the territory of the Member States [2004] OJ L158/77.

14 Council Directive 2003/109/EC of 25 November 2003 concerning the status of thirdcountry nationals who are long-term residents [2004] OJ L16/44.

15 Council Directive 2003/86/EC of 22 September 2003 on the right of family reunification [2003] OJ L251/12.

16 The reasoning in Pace v Alabama 106 U.S. (16 Otto) 583 (1883), concerning an appeal to equal protection to strike down a statute prohibiting interracial sex, was dismissed by reasoning identical to that of the ECJ in Grant: blacks should be compared with blacks and whites with whites, while heterosexuals should not be compared with gays. The US Supreme Court abandoned such an approach to equality in McLaughlin and Loving. See McLaughlin v Florida, 379 U.S. 184 (1964), 188; Loving v Virginia, 388 U.S. 1 (1967). Cf A Koppelman, 'The Miscegenation Analogy in Europe, or, Lisa Grant meets Adolf Hitler' in R Wintemute and M Andenžs (eds), Legal Recognition of Same-Sex Partnerships: A Study of National, European and International Law (Hart, Oxford/Portland 2001).

17 Most notably, see the UNHRC's decisions in Toonen $v$ Australia [1994] UN Doc CCPR/ C/50/D/488/1992; Young v Australia [2000] UN Doc CCPR/C/78/D/941/2000. See also the ECtHR's judgments in Salgueiro da Silva Mouta v Portugal (App no 33290/96) ECHR 
ing rulings of dubious quality such as $\operatorname{Grant}^{18}$ and $D \&$ Sweden. ${ }^{19}$ Shying away from the equality rhetoric it has used elsewhere,${ }^{20}$ it instead offers a body of 'decisions [that] are irreconcilable and incoherent'. ${ }^{21}$

Secondly, the Community legislator has not been bold enough to safeguard the non-discrimination principle against Member States' 'sensitivities'. The result of this timidity on the part of the institutions responsible for drafting the aforementioned directives is that recognition of gay couples' rights in the EC depends on the law of the Member State where they reside. ${ }^{22}$ Not providing universal recognition of same-sex partnerships all over the EU renders the effet utile of such provisions minimal, since countries already recognising such partnerships could also recognise foreign partnerships by applying international private law. The same applies to family reunification matters, ${ }^{23}$ where gay people residing in certain Member States are de facto hostages of public prejudice vis-à-vis sexual minorities there. Moreover, the limited scope of Directive $2000 / 78 / \mathrm{EC}$, which deals only with equal treatment in employment and

1999-IX; Karner v Austria (App no 40016/98) ECHR 2003-IX (but also see Fretté v France (App no 36515/97) ECHR 2002-I, ruling that the principle of non-discrimination based on sexual orientation does not apply to the right to adopt children established by Article 343-1 of the French Civil Code).

18 Case C-249/96 Grant [1998] ECR I-621. For discussion, see eg J McInnes, 'Case C249/96' (1999) 36 CML Rev 1043; CD Rasnic, 'The Latest Pronouncement from the European Court of Justice on Discrimination against Homosexuals: Grant $v$ South-West Trains Ltd' (1999) 12 New York Intl LR 79; LR Helfer, 'Grant $v$ South-West Trains, Ltd Case C-249/96' (1999) 93 AJIL 200; K Berthou and A Masselot, 'La CJCE et les couples homosexuelles' (1998) 12 droit social 1034.

19 Cases C-122/99P \& C-125/99P D \& Sweden [2001] ECR I-4319. For discussion, see eg E Ellis, 'Cases C-122 \& 125/99P' (2002) 39 CML Rev 151; K Berthou and A Masselot, 'Le marriage, les patenariats et la CJCE: Ménage à trois' (2002) CDE 679. For an analysis of the case's outcome in the first instance (T-264/97), see C Denys, 'Homosexuality: A Non-Issue in Community Law' (1999) 24 EL Rev 419.

20 The ECJ referred to a 'general principle of equality' in Case 117/76 Ruckdeschel et al $v$ Hauptzollamt Hamburg-St Annen [1977] ECR 1753 para 7. Among recent examples of the ECJ's invocation of the general principle of equality in Community law, with an interesting use of comparisons, is Case C-300/04 Eman and Sevinger $v$ College van burgemeester en wethouders van Den Haag [2006] 16 September 2006. There the Court compared Dutch nationals living on Aruba with those living in other third countries, thus giving the principle of equality a very wide reading indeed, and not backing it with any references to specific articles in the Treaties.

${ }^{21}$ B Carolan, 'Judicial Impediments to Legislating Equality for Same-Sex Couples in the European Union' (2005) 40 Tulsa LR 527, 532. See also A Williams, 'An Evaluation of the Historical Development of the Judicial Approach to Affording Employees Protection against Discrimination on the Basis of Their Sexual Orientation' (2004) Business LR 32; I Canor, 'Equality for Lesbians and Gay Men in the European Community Legal Order - "They Shall Be Male and Female"?' (2000) 7 MJ 273; N Bamforth, 'Sexual Orientation Discrimination after Grant v South-West Trains' (2000) 63 MLR 694, 720.

22 Art 2(2)(b) Directive 2004/38/EC [2004].

23 See Section II below. 
occupation, provides insufficient defence against discrimination. ${ }^{24}$ This is especially clear if the scope of Directive $2000 / 78 / \mathrm{EC}^{25}$ is compared to that of Directive 2000/43/EC, ${ }^{26}$ likewise adopted pursuant to Article 13 $\mathrm{EC}$ and applicable to a broader array of situations. ${ }^{27}$

Thirdly, negative trends concerning gay rights protection may be noted in some of the new Member States from Eastern Europe, despite the thorough pre-accession monitoring conducted by European institutions before welcoming these countries as full members of the Union. Although it would be exaggerated to warn of a possible 'homophobic spill-over' from the East, the situation is nevertheless quite alarming. It is clear that, in the process of pre-accession monitoring, the Commission and other institutions failed to put a persuasive gay-rights message across to the new Member States. ${ }^{28}$ The negative consequences of such negligence are absolutely clear in the context of developments in Poland and Latvia. As a consequence of this missed opportunity (ie effectively using the pre-accession process to prepare the ground for tolerant, inclusive and nondiscriminatory treatment of gays in the countries of Eastern Europe prior to their accession to the Union ${ }^{29}$ ) and the post-enlargement shift in the EU's institutional dynamics, in which the new Member States inevitably gained in importance, the effectiveness of future moves by the EU concerning gay rights protection will likely be undermined. This is already the case in the European Court of Human Rights (ECtHR), which has narrowed the meaning of non-discrimination based on sex, with a majority of Eastern European judges on the panel. ${ }^{30}$ The same conclusion can be drawn by reading the minutes of debates in the European Parliament on such issues as non-discrimination based on sexual orientation and the

\footnotetext{
24 Interestingly, the EP had proposed to deal with this issue as early as 1984: European Parliament, 'Resolution on sexual discrimination in the workplace' [1984] OJ C104/46.

25 See eg Art 1 Directive 2000/78/EC, clearly stating the Directive's purpose as combating discrimination 'as regards employment and occupation', thus excluding all other instances of discrimination.

26 Council Directive 2000/43/EC of 29 June 2000 implementing the principle of equal treatment between persons irrespective of racial or ethnic origin [2000] OJ L180/22.

27 See Art 1 Directive 2000/43/EC.

28 See Kochenov (n 11) passim.

29 The pre-accession assessment of gay rights conducted by the Commission in candidate countries was no less diligent than its analysis of other equality issues: see eg D Kochenov 'The Summary of Contradictions: The EU's Main Internal and External Approaches to Ethnic Minority Protection Outlined' (2007) Boston College Intl \& Comp LR (forthcoming). On the use of conditionality by the Commission generally, see D Kochenov, EU Enlargement: The Failure of Conditionality. Pre-accession Conditionality in the Fields of Democracy and the Rule of Law (Kluwer Law International, The Hague) (forthcoming).

30 Besides the French judge, those voting de facto to overrule Salgueiro da Silva Mouta in Fretté $v$ France included judges from Lithuania, the Czech Republic and Albania. Judges who voted against were from Austria, Belgium and the UK.
} 
fight against homophobia. Polish MEPs tend de facto to oppose progress in these areas, asking meaningless rhetorical questions such as: 'Do we have the right to impose our way of thinking on voters, or to tell them how they should approach the problem of sexuality and sexual minorities?'31 With such questions as a starting point in a debate on equality, politicians become nothing more than an instrument for reinforcing the hateful prejudices of the majority, making any progress towards equality unthinkable. ${ }^{32}$

These three disturbing lines of development are closely connected to each other. The Commission did not treat the issue of gay rights protection seriously in the pre-accession phase because of the ECJ's unwillingness to interpret the Treaty in such a way as to promote non-discrimination based on sexual orientation as an inherent part of the acquis communautaire, and also because of the Treaty's own ambiguity in this respect. Thus, on the one hand, as stated by Mr Flynn on behalf of the Commission in 1996, 'the issue of the eradication of discrimination on grounds of sexual orientation is directly linked to the broader issue of fundamental rights and freedoms'. ${ }^{33}$ On the other hand, the status of gay rights protection in the Community prior to the adoption of Directive 2000/78/EC was far from encouraging. As summarised by the same Commissioner, the status quo was that 'the Treaty on European Union does not confer specific powers on the institutions to eradicate discrimination on grounds of sexual orientation'. ${ }^{34}$ In other words, the Commission was confined to a somewhat reserved approach to this issue by the state of European law at the time. Consequently, in promoting gay rights during pre-accession monitoring, the Commission had only 'slight' backing from the acquis, thus making the effective promotion of gay rights in the candidate countries difficult. ${ }^{35}$ With the Court reluctant to include non-discrimination based on sexual orientation within the scope of sex-

31 See the remarks by Barbara Kudrycka MEP in the debate on the Resolution on homophobia in Europe of 16 January 2006, PV 16/01/2006-14.

32 See also the remarks by Konrad Szymańsky MEP in the debate on the Resolution on homophobia in Europe of 16 January 2006, PV 16/01/2006-14, arguing that debating homosexuality and equality issues makes no sense, since 'fortunately' MEPs cannot do anything in this matter, initiative resting instead with the Member States.

33 Written Question 2224/96 [1996] OJ C356/95.

34 Ibid. Cf Written Questions 2133/83 [1984] OJ C173/9 and 2134/83 [1984] OJ $\mathrm{C} 152 / 25$.

35 Difficult, but not impossible, given that the scope of the Copenhagen criteria did not coincide entirely with that of the acquis communautaire in the pre-accession context, granting the Commission more freedom in dealing with the candidate countries than it would otherwise enjoy with fully-fledged Member States: D Kochenov, 'Why the Promotion of the Acquis Is Not the Same as the Promotion of Democracy and What Can Be Done in Order to Also Promote Democracy instead of Just Promoting the Acquis' (2006) 2(2) Hanse LR 169 <http://papers.ssrn.com/sol3/papers.cfm?abstract_id=953812> accessed 31 July 2007. 
based non-discrimination, the unfortunate gay rights situation in the EU could not easily be changed. However, the ECJ's unwillingness to be more receptive to the needs of gay EU citizens was only part of the problem. The Community legislator was also clearly restrained by the cautious approach to gay rights adopted by certain Member States. Consequently, it has become obvious that progress in the area of gay rights in the EU requires an orchestrated effort, with all the parties concerned working together to resolve issues in all three of the problem areas mentioned and thus break this apparently vicious circle.

That said, it seems somewhat premature to adopt an overly grim view of the reality of gay rights protection in the EU. Directive 2000/78/EC itself is testimony to a changing climate of tolerance in the Union. ${ }^{36}$ Not only should the Directive make new cases like Grant impossible, ${ }^{37}$ but it also draws on Article 13 EC, introduced by the Treaty of Amsterdam, to reverse the situation that characterised gay rights protection before the start of the present century. The 1996 statement by then-Commissioner Flynn, ie that the EC does not have powers in this area, no longer reflects the legal reality of the Community. This is nothing less than a huge leap forward. Likewise, the Member States' positions are evolving in a mainly positive way: more and more countries are allowing gay marriages or civil unions, while the relevant national non-discrimination legislation in force in the Member States is quite advanced, certainly much more advanced than that found in the Union before Amsterdam. Moreover, the judiciaries of Member States, including those in Eastern and Central Europe that have only recently joined the Union, have demonstrated their ability and willingness to protect the rights of sexual minorities. Polish court verdicts condemning the banning of Equality Parades in Warsaw in 2004 and 2005 may be cited as examples of such developments. ${ }^{38}$ Nonetheless, what becomes clear after weighing recent developments in gay rights protection in the EU and its Member States is that much effort is still needed on the part of all involved in order to improve the situation.

\footnotetext{
36 For scholarly analysis of the legal situation in the Union prior to the inclusion of Article 13 EC by the Treaty of Amsterdam and the adoption of the Directive, see eg B Carolan, 'Rights of Sexual Minorities in Ireland and Europe: Rhetoric versus Reality' (2001) 19 Dickinson J Intl L 387.

37 Unfortunately, while case law on sex-based non-discrimination in relation to transsexuals is abundant (eg Case C-423/04 Sarah Margaret Richards $v$ Secretary of State for Work and Pensions [2006] ECR I-3585; Case C-117/01 KB v National Health Service Pensions Agency, Secretary of State for Health [2004] ECR I-541; Case C-13/94 P v S [1996] ECR I-2145; see also P Skidmore, 'Commentary: Sex, Gender and Comparators in Employment Discrimination' (1997) 26 Industrial LJ 51), no new cases where homosexuality was at issue have been decided by the ECJ.

38 The banning of the parade by the then-mayor of Warsaw, Mr Kaczy ski, was ruled illegal in September 2005.
} 
This article first outlines the main developments in EC law that have led to the present level of gay rights protection in Europe. It also highlights the weaknesses of existing EC law (Section I). Next, the focus shifts to the East, to see how the new Member States are dealing with the obligations imposed on them by Community law to protect gay rights and ensure that sexual minorities do not suffer discrimination (Section II). Having identified the weak spots in gay rights protection in Europe, EU developments in this area are put in the larger context of gay rights protection in other jurisdictions. Clearly, while the EU is by far not the worst in the world in this regard, it is not the best, either (Section III). The Conclusion outlines a way of resolving some of the outstanding gay rights problems in the Community, and indicates the way forward for the development of EU equality law. The EU should capitalise on its achievements and make progress in the area of gay rights protection, carrying the most conservative Member States along with it.

\section{EU Law and Gay Rights: Main Developments and Weak Points}

Before the entry into force of the Treaty of Amsterdam, which introduced Article 13 into the EC Treaty, the Union had no competence in this domain, and thus could not legislatively prohibit discrimination based on sexual orientation. ${ }^{39}$ Negative integration in this area was rejected by the Court of Justice, notwithstanding the fact that, theoretically, the possibility of interpreting the law differently was quite evident.

The European Convention on Human Rights (ECHR), as interpreted by the ECtHR, can be used to illustrate this point. Although it does not prohibit discrimination based on sexual orientation directly, the ECHR's non-discrimination provision ${ }^{40}$ has been interpreted by the ECtHR to include sexual orientation among the prohibited grounds of discrimination. ${ }^{41}$ Moreover, certain rights of gays fall within the scope of Article 8 ECHR. ${ }^{42}$

Since the ECHR does not bind the ECJ directly, ${ }^{43}$ but rather merely possesses a 'special significance' 44 in Community law and provides, ac-

\footnotetext{
39 This section draws heavily on Kochenov (n 11) s IV.

40 Art 14 ECHR.

${ }^{41}$ ECtHR Salguero da Silva Mouta [1999] App no 33290/96 paras 34-36; ECtHR Fretté [2002] App no 36515/97 para 26.

42 ECtHR Dudgeon $v$ UK (App no 7525/76) (1983) Series A no 45; ECtHR Norris (App no 10581/83) (1988) 13 EHRR 186; ECtHR Modinos v Cyprus (App no 15070/89) (1993) Series A no 259. Other articles (especially Articles 10 and 11 ECHR) are also potentially applicable; see CB Rabinowitz, 'Proposals for Progress: Sodomy Laws and the European Convention on Human Rights' (1995) 21 Brooklyn J Intl L 425.

43 DJ Harris, M O'Boyle and C Warbrick, Law of the European Convention on Human Rights (London: Butterworths, London 1995) 27, 28.

44 Case C-299/95 Kremzow v Austria [1997] ECR I-2629 para 14; Case C-260/89 ERT v DEP [1991] ECR I-2925 para 41.
} 
cording to Article 6(2) EU and ECJ case law, ${ }^{45}$ a source for the principles of Community law, it is up to the ECJ to recognise pro-gay rights elements in the Convention's provisions and try to incorporate them into Community law.

The Court appears unprepared to move in this direction. Having taken an active pro-egalitarian stand in the $P v S$ case ${ }^{46}$ where it recognised the dismissal of a transsexual employee who intended to undergo gender reassignment as discrimination based on sex, ${ }^{47}$ the Court disappointed gay rights activists by changing its position in subsequent case law.

In the Grant case, which was 'logically indistinguishable' 48 from $P v$ $S$, and concerned granting travel concessions to the same-sex partner of an employee of the South-West Trains Company, the ECJ did not follow the $P v S$ rule, de facto reducing it only to cases involving transsexuals. ${ }^{49}$ The providing of travel concessions in Grant was predicated on the spouse's or partner's being of the opposite sex from the employee. The Court found that Community law prohibiting sex discrimination could not be used here, and that it did not prohibit discrimination based on sexual orientation. The Court interpreted same-sex relationships as being different by their very nature from opposite-sex ones, thus allowing it not to apply the equality principle and refuse to equate homosexual couples with heterosexual ones. Confirming 'a stereotyped notion of European family ${ }^{50}$ in $D \&$ Sweden $v$ Council, ${ }^{51}$ the Court found that the situation of an official who registered a partnership with a person of the same sex in Sweden 'cannot be held to be comparable [...] to that of a married official', ${ }^{52}$ ruling that only married (ie heterosexual) couples were entitled to a family allowance under the Staff Regulations.

45 Case C-185/97 Coote v Granada Hospitality Ltd [1998] ECR 5199 paras 21-23; Case 22/84 Johnston $v$ Chief Constable of the Royal Ulster Constabulary [1986] ECR 1651 para 18.

46 Case C-13/94 P v S [1996] ECR I-2145. See also L Flynn, 'Case C-13/94' (1997) 34 CML Rev 367; Skidmore (n 37).

47 Under Council Directive 76/207/EEC of 9 February 1976 on the implementation of the principle of equal treatment for men and women as regards access to employment, vocational training and promotion, and working conditions [1976] OJ L39/40.

48 Koppelman (n 16) 632.

49 Probably because of the ECJ's willingness to deal with discrimination against transsexuals within the framework of discrimination based on sex, neither Article 13 EC nor Directive 2000/78/EC cover trans-gender discrimination: see Answer by Mrs. Diamantopoulou on behalf of the Commission to Written Question E-1842/02 by Glyn Ford to the Commission [2003] OJ E52/106 paras 2, 3.

50 E Reid and E Caracciolo di Torella, 'The Changing Shape of the "European Family" and Fundamental Rights' (2002) 27(1) EL Rev 80, 84.

51 Cases C-122/99P \& C-125/99P D \& Sweden [2001] ECR I-4319.

52 Cases C-122/99P \& C-125/99P D \& Sweden [2001] ECR I-4319 para 51. 
The relevant case law to date is remarkable in at least three respects, all of them closely interrelated. Firstly, the Court makes a clear distinction between transsexuals and gays, applying the sex discrimination test to the former while refusing to do so for the latter. Consequently, its case law on the rights of transsexuals is in much better accord with human rights principles than its case law on the rights of homosexuals. However, the fact remains that a strong argument can be made in favour of regarding discrimination based on sexual orientation as sex discrimination. ${ }^{53}$

Secondly, the Court's test in gay rights discrimination cases involves, bizarrely, a comparison of the situation of homosexual men to that of lesbian women, not to that of heterosexuals. Thus a male homosexual couple is compared to a lesbian couple, and no discrimination is found. Such a choice of comparator involves a double change, and thus does not withstand the simplest logical test: comparing two men to two women involves a change in the sex of both the person in question and his or her partner, ${ }^{54}$ revealing 'a true perversion of the common-sense notion of equality'. ${ }^{55}$

Thirdly, the ECJ refused to apply ECHR standards of non-discrimination based on sexual orientation, regarding itself as legally incompetent to enlarge the scope of the Community's powers. ${ }^{56}$ This argument, which could be expected after Opinion 2/94 ([1996] ECR I-1759), is a boringly superficial one, given that, in the early days of integration, human rights protection was not included in the Founding Treaties at all, and the Court moved to protect human rights more or less on its own initiative, relying on the 'constitutional traditions of the Member States' and the principles of the ECHR. ${ }^{57}$ There is no case law on the issue of non-discrimination based on sexual orientation. It can only be hoped

\footnotetext{
53 A Koppelman, 'Why Discrimination against Lesbians and Gay Men Is Sex Discrimination' (1994) 69 New York U LR 197; R Wintemute, 'Recognising New Kinds of Direct Sex Discrimination: Transsexualism, Sexual Orientation and Dress Codes' (1997) 60 MLR 334, 344-353; Bamforth (n 21) 701 ff. On difficulties in defining sex, see JA Greenberg, 'Defining Male and Female: Intersexuality and the Collision between Law and Biology' (1999) 41 Arizona LR 265.

54 McInnes (n 18) 1050.

55 Carolan (n 37) 405.

56 Case C-249/96 Grant [1998] ECR I-62 1 para 45.

57 See eg Case 29/69 Erich Stauder $v$ City of Ulm - Sozialamt [1969] ECR 419 para 7; Case 11/70 Internationale Handelsgesellschaft $\mathrm{mbH} v$ Einfuhr- und Vorratstelle für Getreide und Futtermittel [1970] ECR 1125; Case 4/73 J Nold, Kohlen- und Baustoffgroßhandlung v Commission [1974] ECR 491. For an analysis of this process, see JR Wetzel, 'Improving Human Rights Protection in the European Union: Resolving the Conflict and Confusion between the Luxembourg and Strasbourg Courts' (2003) 71 Fordham LR 2823, 2834ff; HG Schermers and DF Waelbroeck, Judicial Protection in the European Communities $\left(6^{\text {th }}\right.$ edn Kluwer, The Hague/London/New York 2001) 38-46.
} 
that recent legal developments will allow the Court to change its position and start providing better protection against discrimination for gays.

The legislator's response to ECJ case law came in the form of Council Directive 2000/78/EC, adopted on the basis of Article 13 EC. The Directive outlawed discrimination based on sexual orientation ${ }^{58}$ 'as regards to employment and occupation'. ${ }^{59}$ The problems related to the limited scope of application of this non-discrimination instrument are evident. A number of MEPs were outspoken in their criticism of the Directive's limited nature. Kathalijne Buitenweg, for instance, wondered: 'why is the right to equal treatment of people, irrespective of their sexual orientation, restricted to the labour market?'60 The gap between the scope of the Race Directive (2000/43/EC) and Directive 2000/78/EC is as huge as it is inexplicable, and should clearly be bridged as soon as possible. Why should discrimination based on sexual orientation be allowed, for instance, when renting a house or in other situations that have nothing to do with employment relationships? Why should one directive cover more instances of discrimination than another? Alarmingly, a hierarchy seems to have arisen among 'equalities' in Community law, ${ }^{61}$ with some vulnerable groups enjoying better protection than others, without any possible explanation as to why this difference in treatment is there in the first place. The wording of Article $13 \mathrm{EC}$ seems to leave ample room to move forward on nondiscrimination. Although it spells out only the possibility of acting "without prejudice to other provisions of this Treaty and within the limits of the powers conferred by it upon the Community', ${ }^{62}$ when read in conjunction with the goals of the Community spelt out in Article 2 EC, especially those of the common market, ${ }^{63}$ it becomes clear that a move towards outlawing discrimination based on sexual orientation in other areas is not only possible, but also necessary. The clear need for a new, more inclusive legal instrument at the Community level, based on Article 13 EC and outlawing discrimination, has been articulated on numerous occasions, the most recent being the European Parliament's call for a new non-discrimination directive that would have a general application and cover all the grounds

58 Sexual orientation is also one of the grounds on which discrimination is prohibited by Article 21(1) of the (proclaimed, but not binding erga omnes) Charter of Fundamental Rights of the European Union [2000] OJ C364/01, and also forms part of the unfortunate Treaty Establishing a Constitution for Europe in its Article II-81(1).

59 Art 1 Directive 2000/78/EC.

60 See the remarks by Kathalijne Maria Buitenweg MEP in the debate on the Resolution on homophobia in Europe of 16 January 2006, PV 16/01/2006-14.

61 Waddington and Bell (n 2) 586. See also L Flynn, 'The Implications of Article 13 EC After Amsterdam Will Some Forms of Discrimination Be More Equal than Others?' (1999) 36 CML Rev 1127.

62 Article 13(1) EC.

63 As clarified in Article 14(2) EC as well. 
mentioned in Article 13 EC. ${ }^{64}$ The European Parliament regards adoption of such a directive as the "completion of the anti-discrimination package based on Article 13 of the [EC] Treaty'. ${ }^{65}$

Other recent legislative acts at the Community level demonstrate the reluctance of the EC and its Member States to move towards better protection of gay rights. Directive 2004/38/EC on the free movement of citizens, for instance, does not view same-sex couples and spouses as equal to heterosexual couples, recognising the former only in countries where same-sex unions are recognised. ${ }^{66}$ Clearly, creating two types of families/unions for the purposes of EC law, depending on the Member State of residence chosen by the couple, is not at all in line with the idea of uniform and effective application of EC law throughout the entire territory of the EU. ${ }^{67}$ Examining the ECJ's free movement case law, it is easy to demonstrate, for instance, that citizens of Member States where same-sex couples enjoy recognition will be deterred from moving to Member States where this is not so, to the detriment of free movement principles. ${ }^{68}$ This flaw in the Directive will have to be addressed by the Community legislator in the near future. ${ }^{69}$ Moreover, treating same-sex couples differently from heterosexual couples amounts to discrimination, as prohibited by Article 14 ECHR. ${ }^{70}$

Notwithstanding the fact that the ECJ regards respect for family life as a fundamental right, ${ }^{71}$ the state of development of EU family law is truly embryonic, ${ }^{72}$ and there are no provisions of Community law that would provide definitions for such notions as 'spouse' or 'marriage'. ${ }^{73}$ Consequently, protection for same-sex unions throughout the EU is totally lacking, ${ }^{74}$ making it de facto more difficult for members of such un-

64 See European Parliament, 'Resolution on homophobia in Europe' (2006) (n 5) para 8.

65 European Parliament, 'Resolution on homophobia in Europe' (2007) (n 5) recital F.

66 Art 2(2)(b) Directive 2004/38/EC.

67 For a critique of the Directive, see M Bell, 'Holding Back the Tide? Cross-Border Recognition of Same-Sex Partnerships within the European Union' (2004) 5 Eur Rev Private L 613.

68 Eg Case C-370/90 Rv Immigration Appeal Tribunal and Surinder Singh, ex parte Secretary of State for Home Department [1992] ECR I-4265 paras 19, 20.

69 Problems with recognising same-sex unions are similarly acute in the US: A Koppelman, 'Interstate Recognition of Same-Sex Civil Unions after Lawrence $v$ Texas' (2004) 65 Ohio State LJ 1265.

70 ECtHR Karner $v$ Austria [2003] App no 40016/98.

71 Eg Case 12/86 Meryem Demirel v Stadt Schwäbisch Gmünd [1987] ECR 3719 para 28.

72 E Caracciolo di Torella and A Masselot, 'Under Construction: EU Family Law' (2004) 29 EL Rev 32.

73 See Case 59/85 Netherlands $v$ Reed [1986] ECR 1283.

74 In $D \&$ Sweden the ECJ clearly linked the notion of family with the different sexes of the spouses (para 51). The CFI has also been unwilling to reinterpret the meaning of 'family'; see Case T-65/92 Monique Arauxo-Dumay v Commission [1998] ECR II-597 para 30. 
ions to enjoy their EU legal rights ${ }^{75}$ and thus creating yet another group of second-class EU citizens. ${ }^{76}$ As a consequence, a certain 'European conjugal hierarchy'77 sanctioned by the ECJ has been put into place, with registered heterosexual marriage at the top of the pyramid. The changing of the Staff Regulations ${ }^{78}$ to avoid future $D \&$ Sweden situations cannot be regarded as a turning point in this regard, due to their limited application in comparison to all the same-sex couples within the scope of Community law who do not happen to be EC civil servants. The Commission was quite clear in dismissing any possible effects of national legislation on same-sex partnerships and marriages in 'imposing on other Member States an extended definition of spouse'79 or 'extending the notion of spouse under Article 10 of Regulation 1612/68'80 to all the Member States.

Identical problems have arisen from the recent directives on the free movement of third-country nationals who are long-term residents ${ }^{81}$ and on family reunification. ${ }^{82}$ Given the goal-oriented reading of Community competences, surely it would be possible to regulate the definition of the family for the purposes of Community law so as to cover same-sex unions and ensure the genuine protection of free movement for all persons in the common market (including third-country nationals who are long-term residents).

An examination of legal provisions affecting the life of sexual minorities invites comparison with the law on non-discrimination against ethnic minorities. Such comparisons, if not possible in detail, are certainly necessary at the level of principle. The main approach to the legal regulation of ethnic minorities adopted in the current literature is pro-

75 L Papadopoulou, 'In(di)visible Citizens(ship): Same-sex Partners in European Union Immigration Law' (2002) 21 Ybk Eur L 229; B Guiguet, 'Le droit communautaire et la reconnaissance des partenaires de même sexe' (1999) CDE 537.

76 For an analysis of certain other aspects of second-class citizenship in the EU, see eg D Kochenov, 'European Integration and the Gift of Second Class Citizenship: The Absence of the Tools within the European Legal System to Combat Temporary Discrimination of European Citizens on the Basis of Nationality Institutionalized by the Acts of Accession' (2006) 13 Murdoch U Electronic JL 209 <http://papers.ssrn.com/sol3/papers.cfm?abstract_ id=926853> accessed 31 July 2007.

77 D Borillo, 'Pluralisme conjugal ou hiérarchie des sexualités: La reconnaissance juridique des couples homosexuels dans l'Union européenne' (2001) 46 McGill LJ 875, 910.

78 See Council Regulation (EC/Euratom) 723/2004 of 22 March 2004 amending the Staff Regulations of officials of the European Communities and the Conditions of Employment of other servants of the European Communities [2004] OJ L124/1.

79 Answer to Written Question E-3261/01 by Joke Swiebel to the Commission, given by Mr Vitorino on behalf of the Commission [2003] OJ E28/2.

80 Ibid.

81 Art 16(1) Directive 2003/109/EC, in reference to Art 14(1) Directive 2003/86/EC.

82 Art 4(1)(a) Directive 2003/86/EC, referring only to a 'spouse'. 
viding a two-tier system of protection, consisting of non-discrimination and special rights. Much has been written about this recently, ${ }^{83}$ but the approach itself is not new. It goes back to the Permanent Court of International Justice's jurisprudence in Albanian Schools and related cases, ${ }^{84}$ where the Court made it absolutely clear that simple non-discrimination is never enough when protecting ethnic minorities is at stake. Putting members of minority populations on an equal footing with the majority population is not always sufficient in order to give the needed protection unique to the minority in question. This popular approach, which is virtually taken for granted in the area of ethnic minority protection, is not generally applied to the protection of sexual minorities. This is most regrettable, as it could provide a number of solutions to the outstanding problems that legislators and courts often face when dealing with sexual minority protection issues.

\section{Gay Rights in the (New) Member States}

The situation of sexual minorities in the majority of the new Member States has been highly vulnerable ever since the time when these countries were part of the Soviet bloc. It is problematic to apply the idea of rights in the true sense to Eastern European gays before the fall of the Iron Curtain..$^{85}$ Although democratic transformation brought a number of vital improvements, such as decriminalisation of consensual homosexual acts in states where these were still prohibited, ${ }^{86}$ and saw general progress in the gay rights climate in parallel to the overall process of democratisation in these countries, general prejudice against gays in Eastern European societies is still extremely strong. Although the preaccession process led by the Commission and other institutions prior to EU enlargement brought a number of improvements to the legal situation of gays in Eastern Europe, it was obviously unable to resolve all of the outstanding problems. It can even be argued that it achieved less than

83 W Kymlicka, 'Western Political Theory and Ethnic Relations in Eastern Europe' in W Kymlicka and M Opalski (eds), Can Liberal Pluralism Be Exported? Western Political Theory and Ethnic Relations in Eastern Europe (OUP, Oxford 2001); W Kymlicka, Multicultural Citizenship: A Liberal Theory of Minority Rights (Clarendon Press, Oxford 1995); W Kymlicka, Liberalism, Community and Culture (OUP, Oxford 1989). For a critique of Kimlicka's position, see eg M Galenkamp, 'Speciale rechten voor minderheden? Een commentaar op Kymlicka's Multicultural Citizenship' (1996) 22 Recht en Kritiek 202.

84 PCIJ Advisory Opinion of 6 April 1935 regarding Minority Schools in Albania [1935] PCIJ Rep Series A/B No 64.

85 MJ Torra, 'Gay Rights after the Iron Curtain' (1998) 22 Fletcher Forum World Aff 73, 74, 75.

86 Romania was the last of the new Member States to do so, decriminalising homosexual conduct as late as 2001. See L Turcescu and L Stan, 'Religion, Politics and Sexuality in Romania' (2005) 57 Europe-Asia Studies 291, 292-298; Torra (n 85) 79-81. 
might have been possible, given the powerful pre-accession instruments in the Union's possession and the overwhelming determination of these countries to join the EU. ${ }^{87}$ This possible criticism notwithstanding, the pre-accession process saw the elimination of discrimination in ages of consent for consensual homosexual and heterosexual acts, ${ }^{88}$ a firm prohibition of any move towards criminalising homosexuality, and some important elements of non-discrimination in daily life and, especially, in the workplace (the latter being contained in Directive 2000/78/EC). However, no attention was paid in the pre-accession process to non-discrimination in a wider context, eg the possibility of marriage and civil union, child adoption by homosexual couples, and the like. ${ }^{89}$ Despite focusing on some important issues, the EU failed to outline a broader picture of gay rights during the pre-accession process. The overwhelming societal prejudice against gays that exists in the majority of Eastern European countries has not been directly challenged. As a consequence, the law in a number of the new Eastern European Member States de facto provides much weaker protection of gay rights than that found in their Western European counterparts.

When talking about 'new Eastern European Member States', however, it is very difficult to generalise, since the development of gay rights in these countries may differ greatly. While homosexuality was de facto criminalised in Romania up until 2001, Hungary had already allowed (unregistered) same-sex partnerships with a legal standing well before its accession to the EU. While the Polish authorities have openly tried to discriminate against gay teachers, Slovenia and the Czech Republic recently moved to recognise registered same-sex partnerships, ${ }^{90}$ following the majority of EU-15 Member States. ${ }^{91}$

Gay equality could face challenges in the new Member States due, among other things, to three main negative lines of development. First,

87 Langekamp (n 11); Kochenov (n 11).

88 It is worth noting that, while the EU made accession conditional on progress in these areas, Greece had criminal legislation in force which openly discriminated against gays (eg Amnesty International EUR 25/007/2001). Since the requirements put forward by the Commission in the pre-accession process were not, strictly speaking, part of the acquis communautaire, but were covered by the Copenhagen criteria, the Community was powerless in such matters in relation to its Member States. Consequently, nothing could be done about Greece within the framework of EC law.

89 Although such issues could definitely become part of the pre-accession standards, the Commission has refused to adopt any position concerning them. See Answer to Written Question E-2627/00 by Roberta Angelilli to the Commission, given by Mr Vitorino on behalf of the Commission [2001] OJ E136/57.

90 Since 23 July and 1 July 2006, respectively.

91 Same-sex marriages are recognised in the Netherlands, Belgium and Spain, and samesex partnerships in Denmark, Sweden, Finland, France, Germany, Portugal, Luxembourg and the UK. 
there is the threat that national parliaments will refuse to transpose Directive 2000/78/EC in the proper way, being unwilling to have provisions prohibiting discrimination based on sexual orientation on the books. ${ }^{92}$ Generally speaking, this threat has not materialised in the eastern part of the European continent. The only exception was Latvia, where, in 2006, the Latvian Parliament simply refused to amend national legislation in order to outlaw discrimination based on sexual orientation. ${ }^{93}$ Besides Latvia, which was criticised by the Commission in its 2006 Equality and Non-discrimination Annual Report, ${ }^{94}$ several Member States have lagged behind in implementing the Directive; this applies especially to Luxembourg. (The Commission brought a case against Luxembourg under Article $226 \mathrm{EC}$ for its failure to implement the Directive, and the Court found that the Grand Duchy failed to fulfil its obligations. ${ }^{95}$ ) In short, all the new Member States except Latvia have responded adequately to Community legislative instruments concerning non-discrimination based on sexual orientation. ${ }^{96}$

The second challenge concerns activities by the competent authorities that impinge on the exercise of civil rights by members of the gay community. For instance, Equality Parade prohibitions are still a reality in Eastern European countries, Poland and Latvia in particular. Sexual minorities are denied the possibility of using their constitutional rights to freedom of expression and assembly in order to promote equality and challenge the prejudices of the majority. In banning such events, the authorities do not stop short of making bluntly homophobic statements. The current president of Poland, while still the mayor of Warsaw, was reported to have characterised Equality Parades as 'sexually obscene and offensive to other people's religious feelings' ${ }^{97}$ Criminal prosecution has also been used as a tool for silencing equality activists. In one curious case, likewise in Poland, a public prosecutor charged the head of the

92 Only three out of the twelve new Member States had legislation in place prohibiting employment discrimination based on sexual orientation: the Czech Republic, Slovenia and Romania. See C Waaldijk and M Bonini-Baraldi, Sexual Orientation Discrimination in the European Union: National Laws and the Employment Equality Directive (TMC Asser Press, The Hague 2006) 1.

93 See Amnesty International, 'Latvia: Discrimination Based on Sexual Orientation Is a Human Rights Violation' (2006) EUR 52/001/2006.

94 European Commission, '2006 Equality and Non-discrimination Annual Report' (OOPEC, Luxembourg 2006) 11.

95 Case C-70/05 Commission v Luxembourg (ECJ 20 October 2005); see also Case C-43/05 Commission $v$ Germany (ECJ 23 February 2006).

96 On implementation of the Directive generally, see Waaldijk and Bonini-Baraldi (n 92).

97 As quoted in Amnesty International, 'Poland: LGBT Rights under Attack' (2005) EUR $37 / 002 / 2005$. 
Campaign against Homophobia with insulting Catholics. ${ }^{98}$ However, even in Poland some positive developments in this area can be reported. The 2006 Equality Parade in Warsaw was not prohibited, and police are more and more active in protecting parade marchers from hateful protestors. Moreover, courts in Latvia and Poland have played an important role in assisting the gay community to fight for equality by annulling the local authorities' decisions to prohibit these parades.

The third challenge - one which, again, applies particularly to Poland - is that the public embrace of homophobic discourse is a reality in Eastern European politics, giving rise to openly discriminatory campaigns and parliamentary debate of explicitly homophobic bills, such as a bill in Poland that proposed banning all gay teachers from schools. ${ }^{99}$ Besides being openly illegal and breaching both the spirit and the letter of Directive 2000/78/EC, such a bill sends a clear and alarming signal regarding the state of tolerance and the ideals of equality among those in power in Poland. ${ }^{100}$ One of the country's ombudsmen is busy drafting a list of professions for which 'homosexuals are unfit'. ${ }^{101}$ The European Parliament, alarmed by such developments in Poland, proposed that the Commission react; but no action was taken. Other developments in the country include the often-cited firing of the head of the teacher-training programme, resulting, strangely enough, from the use of ECHR-designed equality manuals at schools. ${ }^{102}$ Advocacy of equality has simply been called 'homosexual propaganda'. ${ }^{103}$

No systematic survey of the relevant political developments in the region during recent years is needed in order to see the irresponsible positions adopted by high-ranking officials concerning the issues of equality and non-discrimination based on sexual orientation. Poland's Lech Kaczyński is not the only leader to have made irresponsible remarks. Aigars Kalvitis of Latvia made the following statement on TV: 'Latvia is a state based on Christian values. We cannot advertise things which are

\footnotetext{
98 See the remarks by Józef Pinior MEP in the debate on the Resolution on homophobia in Europe of 16 January 2006, PV 16/01/2006-14.

99 European Parliament, 'Resolution on homophobia in Europe' (2007) (n 5) recital H.

100 Interestingly, the Polish parliamentarians are reportedly planning to propose anti-gay school legislation at the Community level (ibid recital $\mathrm{J}$ ).

101 European Parliament, 'Resolution on homophobia in Europe' (2007) (n 5) recital L.

102 Ibid, recital N. In response to statements by Polish officials condemning the equality manual on the grounds that schools, instead of promoting equal treatment based on sexual orientation, should be busy explaining "the difference between good and evil, beauty and ugliness [...], explain that homosexual practices lead to drama, emptiness and degeneracy' (ibid), the Secretary-General of the Council of Europe, Terry Davies, stated that if the teaching materials are optional, the values and principles contained therein are certainly not' (ibid recital O).

103 European Parliament, 'Resolution on homophobia in Europe' (2007) (n 5).
} 
not acceptable to the majority of our society. ${ }^{104} \mathrm{He}$ thus de facto equated permitting an Equality March in the country's capital, Riga, with 'advertising' homosexuality. These statements have an obvious effect on public opinion. ${ }^{105}$ As long as such pronouncements are being made by the prime ministers of EU Member States, little progress is to be expected in the area of non-discrimination based on sexual orientation.

Poland and, to a lesser extent, Latvia stand apart from the other new Member States as far as their records on sexual non-discrimination are concerned. ${ }^{106}$ This is both good and bad: good, because only two out of the twelve new Member States seem to face particular problems in this regard; bad, because Poland, as the biggest of all the recently acceded countries, is aspiring to play a somewhat more ambitious role in the European Union than the others. All in all, it appears that the main problems which the new Member States, and particularly Latvia and Poland, are facing with regard to the principle of non-discrimination based on sexual orientation are not so much structural or legal; rather, they are rooted largely in anti-gay prejudice in society. It is good news that courts in these countries have not played along with politicians in ignoring the equality principle, and have protected gay rights. In other words, despite a handful of alarming developments, the gay-rights picture in the new Member States is not at all so grim as might be expected today, several years after enlargement and less than twenty years after regime change. However, one must agree with the European Parliament that 'further action is needed at the EU and national levels to eradicate homophobia and promote a culture of freedom, tolerance and equality among citizens and in legal systems'. ${ }^{107}$

\section{Gay Rights in the World Context}

Viewed in the broader context of world developments, and given that the gay, lesbian and bisexual rights movement has achieved a global scale, ${ }^{108}$ Europe and especially the 'old' EU Member States have not lagged behind the leading world jurisdictions in articulating problems in the gay rights area and trying to tackle them effectively. ${ }^{109}$ This is especially true

104 As quoted in Amnesty International, 'Latvia: Leading Politicians Make Remarks which May Have Incited to Verbal and Physical Attacks' (2005) EUR 52/001/2005.

105 European Parliament, 'Resolution on homophobia in Europe' (2007) (n 5) recital B.

106 See also Amnesty International, 'Poland and Latvia: Lesbian, Gay, Bisexual and Transgender Rights in Poland and Latvia' (2006) EUR 01/019/2006.

107 European Parliament, 'Resolution on homophobia in Europe' (2006) (n 5) recital I.

108 CF Stychin, 'Same-Sex Sexualities and the Globalisation of Human Rights Discourse' (2004) 49 McGill LJ 951.

109 See also KMcK Norrie, 'Constitutional Challenges to Sexual Orientation Discrimination' (2000) 49 ICLQ 755. 
with regard to the legal recognition of same-sex couples, where a number of EU Member States can be ranked alongside Canada, ${ }^{110}$ South Africa, ${ }^{111}$ and the US states of Massachusetts, ${ }^{112}$ California $^{113}$ and Vermont. ${ }^{114}$

The last decade has seen a veritable explosion in the recognition of gay rights around the world. ${ }^{115}$ Numerous jurisdictions, from UN bodies to local and provincial authorities, have demonstrated a willingness to award gay rights adequate protection. ${ }^{116}$ Viewed in this light, the growing recognition of non-discrimination based on sexual orientation in the European Union and its Member States, as well as the rise in the number of European jurisdictions allowing the registration of same-sex partnerships and marriages, comes as a natural development.

At the same time, developments at the Community level, and especially the ECJ's case law, have been lagging far behind the vanguard of gay rights recognition. Moreover, in adopting its decisions in Grant and $D \&$ Sweden, the ECJ was very well aware of international developments in gay rights protection. In Grant, for instance, the Court dismissed the reasoning of the UN Human Rights Committee, which, in Toonen $v$ Australia, had ruled that discrimination based on sexual orientation was included among the grounds of discrimination prohibited by Article 26 of the ICCPR. ${ }^{117}$ The ECJ was reluctant to follow this example, reaffirming that it usually takes ICCPR into account in human rights matters, ${ }^{118}$ but pointing out that following the Committee's interpretation would entail extending the Community's human rights jurisdiction, which it was not entitled to do since 'rights cannot in themselves have the effect of extending the scope of the Treaty provisions beyond the competences of the

110 Egan v Canada [1995] 2 SCR 513; Vriend v Alverta [1998] 1 SCR 1.

111 National Coalition for Gay and Lesbian Equality $v$ Minister of Justice 1999 (1) SA 6.

112 Goodridge $v$ Department of Public Health, 798 N.E.2d 941 (Mass. 2003).

113 Cal Fam. Code $\S$ 297.5(a) (West 2003 \& Supp. 2004).

114 Vt. Stat. Ann. tit. 15, § 1204 (2002); Baker v State of Vermont, 744 A.2d 864 (Vermont Supreme Court 1999). See ML Bonauto, 'The Freedom to Marry Same-Sex Couples in the United States of America' in R Wintemute and M Andenžs (eds), Legal Recognition of SameSex Partnerships: A Study of National, European and International Law (Hart, Oxford /Portland 2001).

115 While welcoming these positive developments, negative developments in numerous jurisdictions should not be forgotten. See eg Amnesty International, 'Human Rights and Sexual Orientation and Gender Identity' (2004) ACT 79/001/2004.

116 These developments notwithstanding, homosexuality is still illegal in 75 world countries, nine of which impose the death penalty for it. See the remarks by Alexander Stubb MEP in the debate on the Resolution on homophobia in Europe, 16 January 2006, PV 16/01/2006-14.

117 Toonen $v$ Australia [1994] UN Doc CCPR/C/50/D/488/1992.

118 Case C-249/96 Grant [1998] ECR I-621 para 44. 
Community'. ${ }^{119}$ It also submitted that the Committee's decisions were not binding, and distanced itself from the interpretation of discrimination given in Toonen. ${ }^{120}$ In view of the fact that the Community is bound by international law, ${ }^{121}$ and given the Court's role in reading fundamental rights principles into the Founding Treaties, it is difficult to fully agree with such an assessment. ${ }^{122}$

The UN Human Rights Committee's later case law demonstrates quite clearly that Toonen was not a deviation from commonly accepted international practice, as the ECJ tried to present it in Grant, ${ }^{123}$ but rather good law which has been further built upon. Following Toonen, the Committee ruled in Young $v$ Australia that there was no legitimate reason to deny same-sex partners the government benefits offered to heterosexual couples. ${ }^{124}$ Accordingly, Young, the partner of an Australian veteran, was entitled to a government pension. ${ }^{125}$ The parallels between this case and $D \&$ Sweden, decided one year later, are obvious.

In Europe, the ECtHR has played a particularly constructive role in the protection of gay rights. It has, among other things, ruled that the criminalisation of homosexual acts between consenting adults is illegal; ${ }^{126}$ prohibited age-of-consent discrimination in criminal legislation targeting same-sex couples; ${ }^{127}$ and employed the non-discrimination principle to overturn a national decision refusing a father custody of his child solely on the ground of his homosexuality. ${ }^{128}$ In Karner, the ECtHR disallowed discrimination between unmarried heterosexual and homosexual couples, ${ }^{129}$ rejecting an Austrian argument relating to the protection of the 'traditional family unit' as 'abstract'. ${ }^{130}$ The dismissal of gays from the armed forces due to their sexual orientation was also declared to be in violation of the Convention; among other things, it violated Article 8 (pri-

\footnotetext{
119 Ibid para 45.

120 Ibid paras 46, 47.

121 Case C-286/90 Anklagemydigheden v P M Poulsen Diva Navigation Corp. [1992] ECR 6019 para 9.

122 For discussion, see Canor (n 21) 287-290.

123 Case C-249/96 Grant [1998] ECR I-621 para 47.

124 Young $v$ Australia [2000] UN Doc CCPR/C/78/D/941/2000.

125 Ibid paras 10 and 12 .

126 ECtHR Dudgeon [1983] App no 7525/76; ECtHR Norris [1988] App no 10581/83. This does not apply to consensual sadomasochistic practices between adult men: ECtHR Laskey, Jaggard and Brown v UK (App nos 21627/93, 21826/93, 21974/93) (1997) 24 EHRR 39.

127 ECtHR Sutherland v UK (App no 25186/94) (2001) ECHR 234.

128 ECtHR Salgueiro da Silva Mouta [1999] App no 33290/96.

129 ECtHR Karner [2003] App no 40016/98.

130 Ibid para 47.
} 
vate life). ${ }^{131}$ Equally informative is the ECtHR case law on transsexuals, which also shows that the Court's approach may be viewed as somewhat more progressive than that of other jurisdictions. Thus it ruled that a male-to-female transsexual was entitled under the right to private life to a pension starting at the age of 60 , which is the pension age for female workers in the UK. ${ }^{132}$

However, even the ECtHR has taken some steps towards a more cautious approach to gay rights protection. In its recent judgment in Fretté, it refused a gay man the right to adopt a child, ${ }^{133}$ ruling that the non-discrimination principle of Article 14 of the Convention, although covering non-discrimination based on sexual orientation, did not apply to this particular situation, and reasoning that the prohibition pursued the legitimate aim of 'protecting health and rights of children' ${ }^{134}$ No scientific evidence was presented by the French government to substantiate such a position. The decision in Fretté totally unexpectedly followed Salgueiro da Silva Mouta, which was logically identical to it, and yet produced a different outcome. As noted above, the majority in Fretté, unlike in Salgueiro da Silva Mouta, was mostly Eastern European. In light of this, the future of gay rights in the European Union can be seen as rather grim, and the danger of Frette majorities in the ECJ and $\mathrm{CFI}^{135}$ is more than real.

\section{Conclusion: More Work to be Done}

A lot still needs to be done in the European Community in order to make non-discrimination based on sexual orientation a reality, and to ensure that the rights of members of sexual minorities are guaranteed. Desirable future developments in this area should move in several directions simultaneously.

First of all, a new directive must be adopted to cover non-discrimination based on sexual orientation in general and outlaw discrimination in

131 ECtHR Lustig-Prean \& Beckett $v$ UK (App nos 31417/96 and 32377/96) (2000); ECtHR Smith $v$ UK (App nos 33985/96 and 33986/96) ECHR 1999-VI.

132 ECtHR Grant $v$ UK (App no 32570/03) ECHR 2006-IV. This case is similar to the ECJ's Case C-423/04 Sarah Margaret Richards $v$ Secretary of State for Work and Pensions [2006] ECR I-3585.

133 Such a right exists in French family law under Article 343-1 of the Civil Code; see n 17.

134 ECtHR Fretté [2002] App no 36515/97. For a critique, see D Borillo and Th PitoisEtienne, 'Différence des sexes et adoption: la "psychanalyse administrative" contre les droits subjectifs de l'individu' (2004) 49 McGill LJ 1048-1051; TW Stone, 'Margin of Appreciation Gone Awry: The European Court of Human Rights' Implicit Use of the Precautionary Principle in Fretté $v$ France to Backtrack on Protection from Discrimination on the Basis of Sexual Orientation' (2003) 3 Connecticut Pub Intl LJ 271.

135 Since the ECJ and CFI issue unanimous judgments, it is very difficult to determine with certainty which judges are responsible for a given decision. 
all spheres, not just discrimination in the workplace. While Article 13 EC clearly offers the possibility of moving in this direction, the Community legislator has done nothing so far in order to make full use of the Article, notwithstanding calls from the EP to do so.

Secondly, the Community legislator and the ECJ should take an active stance vis-à-vis existing legislative loopholes concerning the recognition of same-sex unions in Community law. The prejudices of several Member States should not result in gays being denied the possibility of fully benefiting from their free movement rights under the Treaty. A number of directives will have to be either amended by the legislator or reinterpreted by the ECJ, with a view to guaranteeing that the achievement of common market goals and the free movement of persons is not made to depend on some Member States' unwillingness to come to terms with the changing social reality of the family as an institution.

Thirdly, the Commission should adopt a stricter stance with regard to instances of homophobia in the Member States and, particularly, in the new Member States of Latvia and Poland. No instances of discrimination should be tolerated. Politically, the Union should stand firm in condemning the homophobic hate speech of politicians in the (new) Member States, which only reinforces the atmosphere of intolerance in their societies.

Finally, more attention should be paid to the issue of non-discrimination based on sexual orientation in the course of future accessions. The realities of gay rights protection in the current candidate countries (Croatia, Macedonia and Turkey) should be scrupulously assessed before these states are given the green light to accede.

Although much still needs to be done, the Community is on the right path, giving cause for optimism. Compared with the last decades of the previous century, when the situation of gay rights protection in Community law could only be characterised as total normative disarray, gay rights now occupy an important place among the Community's legal developments. 